\title{
UTILIZATION OF AQUEOUS-TAR CONDENSATES FORMED DURING GASIFICATION
}

\author{
Anna Kwiecińska' ${ }^{1}$ Tomasz lluk' ${ }^{1}$, Mateusz Kochel ${ }^{1}$ \\ 1 Institute for Chemical Processing of Coal, Zamkowa 1, 41-800 Zabrze, Poland, e-mail: akwiecinska@ichpw.pl
}

Received: 2016.08.16

Accepted: 2016.09.26

Published: 2016.11.01

\begin{abstract}
Gasification of solid fuels is an alternative process for energy production using conventional and renewable fuels. Apart from desired compounds, i.e. carbon oxide, hydrogen and methane, the produced gas contains complex organic (tars) and inorganic (carbonizate, ammonia) contaminants. Those substances, together with water vapor, condensate during cooling of the process gas, what results in the formation of aqueoustar condensate, which requires proper methods of utilization. The management of this stream is crucial for commercialization and application of the gasification technology. In the paper the treatment of aqueous-tar condensates formed during biomass gasification process is discussed. The removal of tars from the stream was based on their spontaneous separation. The aqueous stream was subjected to ultrafiltration operated at different pressures. Such a treatment configuration enabled to obtain highly concentrated retentate, which could be recycled to the gasifier, and filtrate, which could be subjected to further treatment.
\end{abstract}

Keywords: gasification, wastewater, treatment, membrane separation

\section{INTRODUCTION}

Gasification of alternative fuels, i.e. biomass, SRFs (solid recovered fuels), etc., is energetically efficient and economically attractive thermal operation, which is regarded as one of the most promising method for energy production (Kotowicz et al. 2013, Stelmach et al. 2008). The process comprises of several stages, which are usually carried out in one reactor, called gasifier. The device is usually operated with a fixed or a fluidized bed, in which process streams are organized in co-current or counter-current flow (Sobolewski et al. 2011, Ruiz et al. 2013, Pytlar 2010). Schemed of basically applied gasifiers are presented in Figure 1.

The mechanism of gasification process can be described by a series of thermochemical reactions, which occur during pyrolysis and combustion. The exemplary set of those reactions is given in Equations 1-5:

$$
\begin{aligned}
& \mathrm{C}+\mathrm{O}_{2} \leftrightarrow \mathrm{CO}_{2} \\
& \mathrm{C}+0.5 \mathrm{O}_{2} \leftrightarrow \mathrm{CO} \\
& \mathrm{C}+2 \mathrm{H}_{2} \leftrightarrow \mathrm{CH}_{4} \\
& \mathrm{C}+\mathrm{H}_{2} \mathrm{O} \leftrightarrow \mathrm{CO}+\mathrm{H}_{2} \\
& \mathrm{C}+\mathrm{CO}_{2} \leftrightarrow 2 \mathrm{CO}
\end{aligned}
$$

As a result of those reactions and with the use of a proper gasification agent (air, oxygen, water vapor, hydrogen, carbon dioxide, etc.), as well as at increased temperature (above $800{ }^{\circ} \mathrm{C}$ ), the conversion of solid substrates to a combustible gaseous product, which is a mixture of carbon oxide and dioxide, hydrogen, methane and water vapor, takes place (Kalina \& Skorek 2006, Sulc et al. 2012, Hand \& Kim 2008).

The gas obtained during the gasification process, except for gaseous products, also contains 


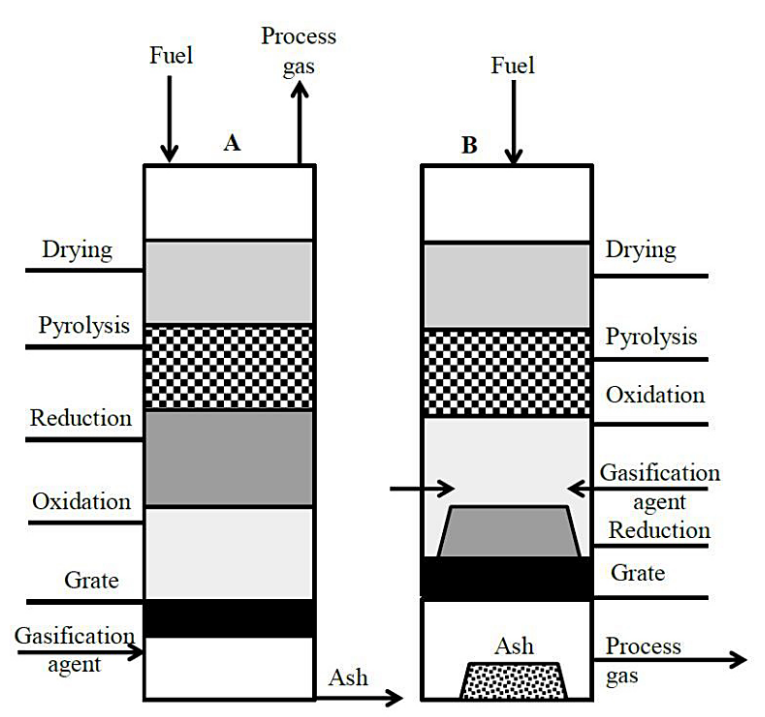

Figure 1. Fixed bed reactor for alternative fuel (SRF) gasification: A - counter-current mode, B - co-current mode

a range of contaminants, which need to be removed before further processing of the process gas, e.g. chemical synthesis or cogeneration. Two gas cleaning methods are used for this purpose, i.e. wet and dry systems. In the former method, contaminants are usually washed out from the gas by means of water or oil absorption in scrubbers and simultaneous cooling of the gas occurs due to its contact with the scrubbing medium. In the latter method, condensable contaminants present in the gas stream appear in a form of aqueous-tar mixture, while solids (dusts and ashes) are usually removed on filters (Hemandez et al. 2013, Tripathi et al. 2013). Regardless of the applied gas cleaning method, highly loaded wastewater containing tars and aqueous stream contaminated with water soluble organic compounds is formed (Figure 2). The proper management of the stream is said to be one of the most important condition for commercialization of biomass gasification, especially in case of medium and small systems (Wnukowski 2012).

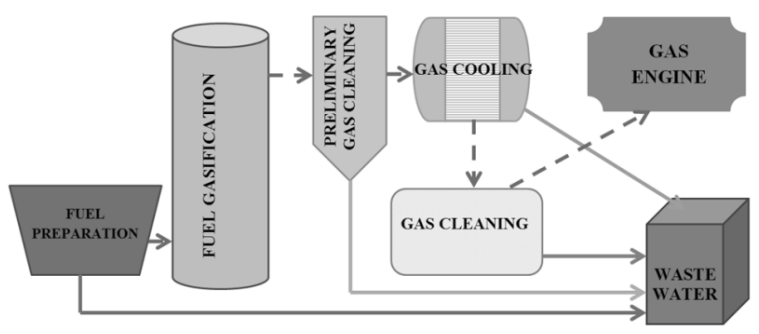

Figure 2. Places wastewater streams formation during gasification process
In the paper, the technique for the treatment of gasification wastewater obtained during the dry cleaning of gas (i.e. tar-water condensate) is discussed. The system based on spontaneous tars separation and membrane filtration for preliminary stream aqueous phase treatment was applied. Polyethersulphone, ultrafiltration membrane of cut off $50 \mathrm{kDa}$ operated at various transmembrane pressures ranging from 0.2 to $0.4 \mathrm{MPa}$ was used.

\section{MATERIALS AND METHODS}

The membrane filtration was carried out in the laboratory installation by $\mathrm{KOCH}$ Membrane Systems, model KMS Cell CF1. The device is equipped with the feed tank of volume $0.5 \mathrm{dm}^{3}$ and two membrane cells arranged in a series of common separation area of $56 \mathrm{~cm}^{2}$. The construction of the device enables to run the process in the cross flow mode. The scheme and the photography of the installation is shown in Figure 3.

In the study, three polyethersulphone, ultrafiltration membrane (trade mark MQ) by Synder Filtration, of the same cut off $50 \mathrm{kDa}$, but operated at different transmembrane pressure, i.e. MQ1, MQ2 and MQ3 membranes, were used. The filtration of gasification condensate was preceded by both, membrane conditioning and characterization with deionized water at transmembrane pressure of $0.1-0.3 \mathrm{MPa}$, as well as by the removal of tars from the treated medium by means of spontaneously occurring sedimentation and floatation of the fraction. Next, the filtration of the aqueous phase of the condensate was carried out at transmembrane pressures range equal to $0.2-0.4 \mathrm{MPa}$, increased by $0.1 \mathrm{MPa}$ by the process. The process performed at MQ1 membrane was carried out at $0.2 \mathrm{MPa}$ pressure, while processes performed at MQ2 and MQ3 membranes were carried out at $0.3 \mathrm{MPa}$ and 0.4 MPa pressures, respectively. All filtrations were run until $80 \%$ of the feed volume was recovered in the form of permeate. After the process, the flux of deionized water was again measured, in order to evaluate the character of fouling of the membrane and possible interactions between membrane material and contaminants present in the treated wastewater.

The feed and filtrates obtained during the process were characterized due to the value of $\mathrm{pH}$, specific conductivity (spec. cond.), chemical oxygen demand (COD), ammonium nitrogen $\left(\mathrm{N}-\mathrm{NH}_{4}\right)$ and dry mass content. $\mathrm{pH}$ and spe- 


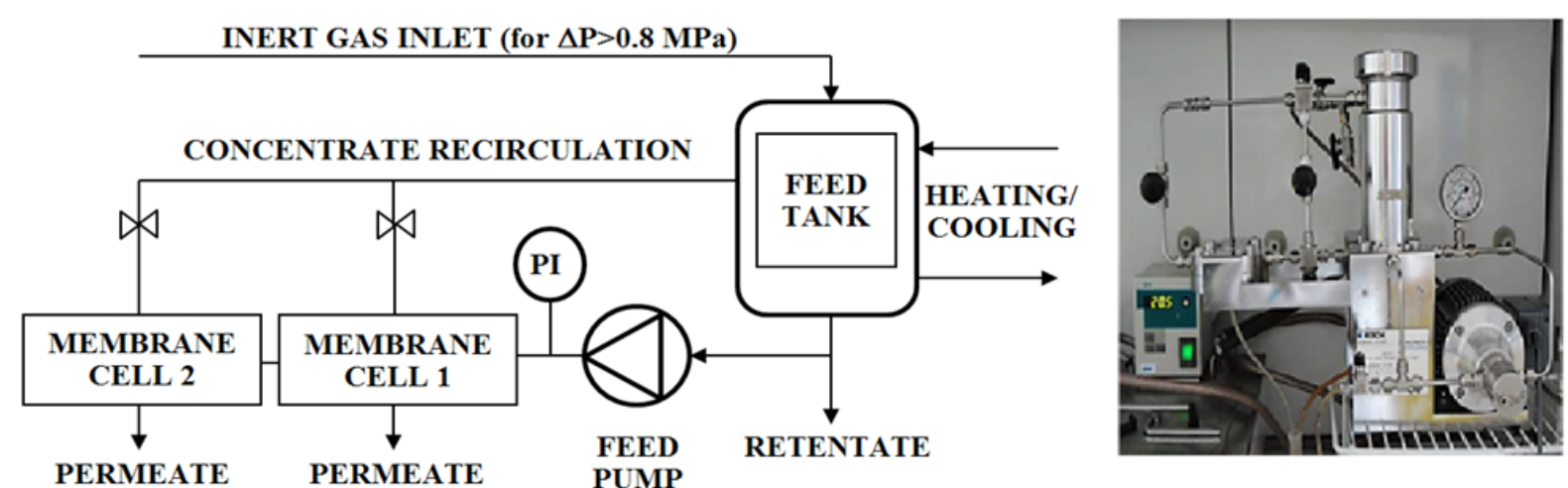

Figure 3. The scheme and the photography of laboratory installation for membrane filtration KMS Cell CF1

cific conductivity were measured with the use of dedicated probes, chemical oxygen demand and ammonia nitrogen were indicated by means of HACH Lange methodology, while dry mass content was analyzed by means of conventional thermal method at $105^{\circ} \mathrm{C}$ temperature.

\section{RESULTS AND DISCUSSION}

\section{Membranes characterization}

In Figure 4, the results on membranes characterization with deionized water are presented. The flux at every transmembrane pressure is a mean value of five measurements.

The characterization of the applied membranes with deionized water revealed that the increase of flux with transmembrane pressure at the investigated pressure range was linear and the determination coefficient established for all membranes was above 0.99 . It was also noticed that despite the same membrane material and cut off, the fluxes at particular pressures were different, especially in case of MQ3 membrane. It is generally accepted for membrane filtration, that such the behavior commonly appears in membrane filtration processes and it is a result of difference in membranes porosity. Hence, for the discussed cases it could be assumed that membranes with higher fluxes (MQ1 and MQ2) characterized with higher porosity than MQ3 membrane.

\section{Gasification wastewater filtration}

In Figure 5, the change of permeate fluxes in time, observed during filtration of gasification wastewater is shown. All processes were carried out until $80 \%$ of the initial feed volume was recovered in a form of the permeate. As it could have been supposed, the process carried out at the lowest transmembrane pressure was the longest one, and fluxes measured during the filtration were the lowest. In case of processes performance at 0.3 and $0.4 \mathrm{MPa}$ pressures both, the duration of the filtration, as well as permeate fluxes were comparable. Hence, the occurrence of fouling on the membrane capacity needed to be compared.

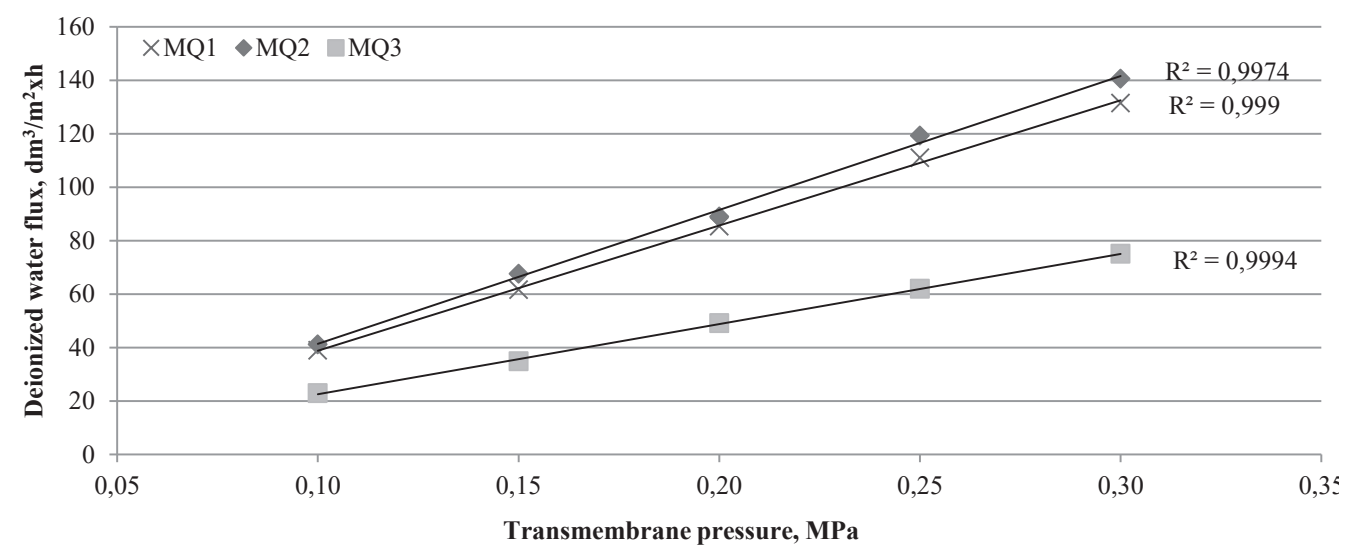

Figure 4. Results of characterization of MQ membranes with deionized water 


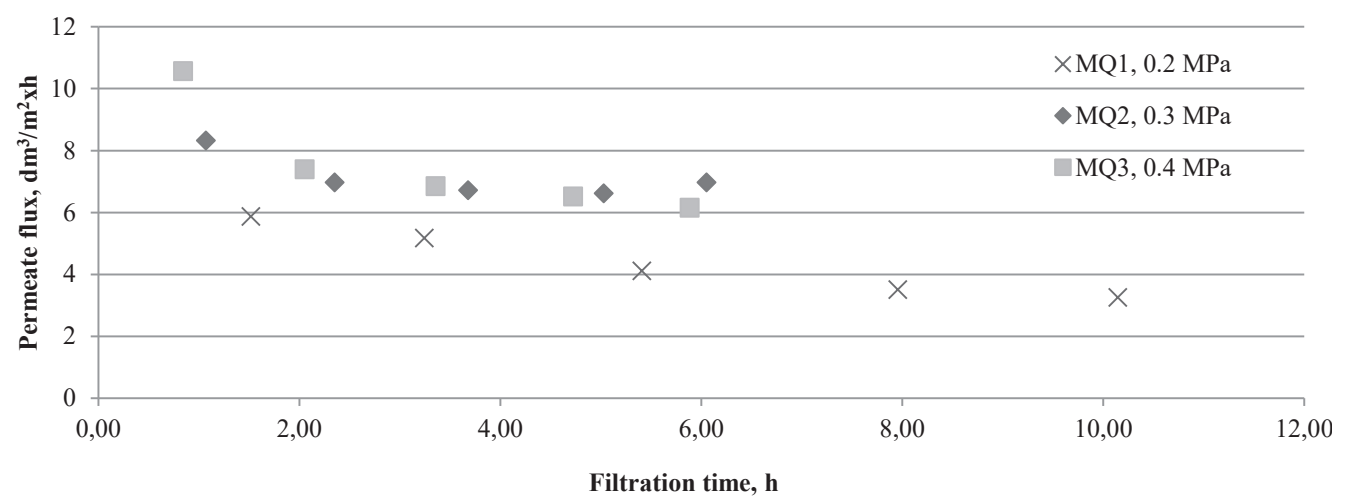

Figure 5. The change of permeate flux in time during filtration of gasification wastewater

For this purpose, relative membrane capacity $\alpha$, expressed as the ratio of average permeate flux to the deionized water flux at the process pressure was compared. The obtained results are shown in Figure 6. Additionally, the filtration of gasification wastewater was proceeded with the measurement of deionized water flux at the process pressure, in order to define the character of occurred fouling. The comparison of deionized water fluxes measured before and after gasification wastewater filtration, as well as relative deionized water fluxes $\alpha$ ' are shown in Figure 7.
It was noticed that the impact of fouling on the process capacity during gasification wastewater filtration was the highest in case of the filtration at $0.3 \mathrm{MPa}$, for which the lowest relative permeate flux at the level of 0.05 was established. However, in case of all investigated processes, the permeate flux did not exceed $10 \%$ of deionized water flux measured for clean membranes. The determined relative deionized water fluxes indicated, however, that the most severe fouling occurred during the filtration at the lowest process pressure, i.e. $0.2 \mathrm{MPa}$. The recovery of initial

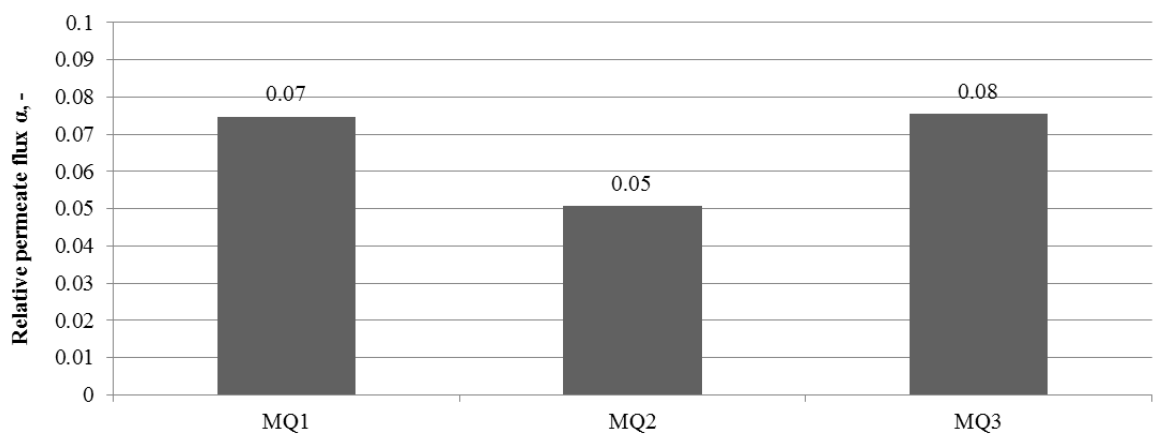

Figure 6. Relative membrane capacity obtained for the filtration of gasification wastewater

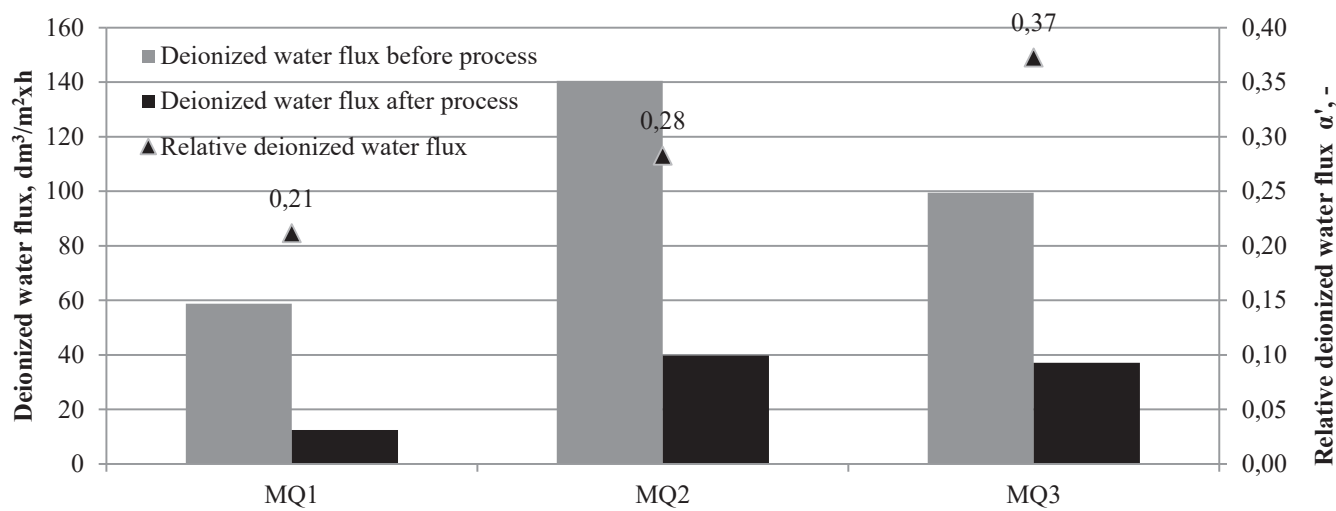

Figure 7. The comparison of deionized water fluxes measured before and after gasification wastewater filtration (at process transmembrane pressure) and relative deionized water fluxes 
membrane capacity for MQ1 membrane was only $21 \%$, while in case of MQ2 and MQ3 membrane it was $28 \%$ and $37 \%$, respectively. Such results were explained by the more intense washing of contaminants out of membrane pores at higher process pressures. Hence, their deposition in pores was instantaneous and they were more capable for washing with water after the process.

\section{Removal of contaminants}

In Table 1 the comparison of examined parameters of process streams, i.e. feed and permeates is presented, while in Figure 8 the noted removal rates of particular compounds are shown.

It was shown that ultrafiltration process enabled to decrease organic contaminants content, expressed as COD, by $30 \%$ and dry mass content by $45 \%$. Additionally, the process resulted in the decrease of specific conductivity by $21 \%$. Hence, the final product, i.e. permeate was preliminary treated and prepared to be implemented either to nanofiltration or to other polishing technique, e.g. ozonation, photocatalysis or activated carbon adsorption. The remained retentate, which was the concentrated aqueous stream of organic compounds could be used for fuel remoistening and recycled to gasifier.

\section{CONCLUSIONS}

The proper utilization of gasification wastewater is crucial for commercialization of the technology based on alternative fuels, i.e. biomass, SRFs, etc., especially in case of small and medium systems. The stream, which is formed during gas cooling and cleaning, is a highly loaded taraqueous mixture, but the system for its treatment needs to be compact and easy to operate.

Hence, in the study, the use of ultrafiltration with polyethersulphone membrane of cut off 50 $\mathrm{kDa}$ as a method for preliminary treatment of gasification wastewater is discussed. The process was carried out at various transmembrane pressures at the range of 0.2-0.4 MPa and the impact of the parameter on the filtration capacity and membrane fouling was investigated. The study revealed, that permeate fluxes measured during the process were low and did not exceed $10 \%$ of the initial membrane capacity (measured as deionized water flux at clean membrane). It was also shown, that the best process parameters were obtained for the highest investigated transmembrane pressure, i.e. $0.4 \mathrm{MPa}$. At this pressure the recovery of the initial membrane capacity was the best and reached $37 \%$. The applied membrane enabled to decrease the content of organic contaminants indicated as

Table 1. Parameters of feed and filtrated obtained during ultrafiltration of gasification wastewater

\begin{tabular}{|l|c|c|c|}
\hline \multicolumn{1}{|c|}{ Parameter } & Unit & Feed & Permeate $^{*}$ \\
\hline $\mathrm{pH}$ & - & 8.96 & 8.85 \\
\hline Spec. conductivity & $\mathrm{mS} / \mathrm{cm}$ & 47.47 & 37.27 \\
\hline $\mathrm{COD}$ & $\mathrm{mg} / \mathrm{dm}^{3}$ & 36807 & 25667 \\
\hline $\mathrm{N}-\mathrm{NH} 4$ & $\mathrm{mg} / \mathrm{dm}^{3}$ & 703 & 687 \\
\hline Dry mass & $\mathrm{mg} / \mathrm{dm}^{3}$ & 34966 & 19250 \\
\hline
\end{tabular}

* The average quality of permeate obtained during performed filtrations.

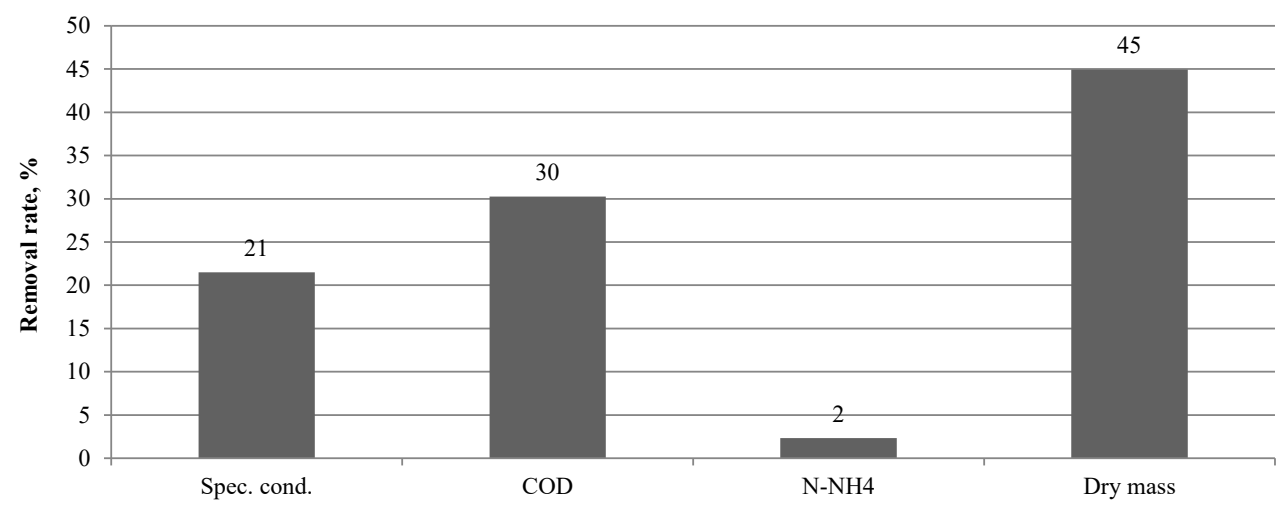

Figure 8. Removal rates of contaminants or their indicators obtained during ultrafiltration of gasification wastewater (in refer to average permeate quality) 
COD by $30 \%$ and the dry mass content by $45 \%$. Hence, the stream of quality suitable to be subjected to further treatment by means of nanofiltration or advanced oxidation was produced.

\section{Acknowledgements}

This work was performed with a financial support of the Ministry of Science and Higher Education under state subsidy no 11.16.008.

\section{REFERENCES}

1. Kotowicz J., Sobolewski A., Iluk T. 2013. Energetic analysis of a system integrated with biomass gasification, Energy, 2, 265-278.

2. Stelmach S., Wasielewski R., Figa J. 2008. Zgazowanie biomasy - przykłady nowych technologii. Archiwum Gospodarki Odpadami i Ochrony Środowiska, 7, 9-20.

3. Sobolewski A., Kotowicz J., Matuszek K., Iluk T. 2011. Reaktory zgazowania biomasy w układach CHP - przyszłość energetyki odnawialnej w Polsce. Polityka Energetyczna, 14(2), 349-360.

4. Ruiz JA., Juarez MC., Morales MP., Munoz P., Mendivil MA. 2013. Biomass gasification for electricity generation: Review of current technology barriers. Renewable and Sustainable Energy Reviews, 18, 174-183.

5. Pytlar TS Jr. 2010. Status of existing biomass gasification and pyrolysis facilities in North America. NAWTEC18.Proc, 1-14.

6. Kalina J., Skorek J. 2006. Uwarunkowania technologiczne budowy układów energetycznych zintegrowanych $\mathrm{z}$ termicznym zgazowaniem biomasy. Energetyka, 537-545.

7. Sulc J., Stojdl J., Richter M., Popelka J., Svobooda K. 2012. Smetana J. Biomass waste gasification can be the two stage process suitable for tar reduction and power generation? Waste Management, $32,692-700$.

8. Han J., Kim H. 2008. The reduction and control technology of tar during biomass gasification/pyrolysis: An overview. Renewable and Sustainable Energy Reviews, 12, 397-416.

9. Hernandez JJ., Ballesteros R., Aranda G. 2013. Characterization of tars from biomass gasification: Effect of the operating conditions. Energy, 50, 333-342.

10. Tripathi L., Dubey AK., Sandip G., Singh PL. 2013. Waste water treatment of biomass based power plant. CODEN(USA): IJCRGG 5(2), 761-764.

11. Wnukowski M. 2012. Methods used in tar removal from biomass gasification gas - a review. Archives of Waste Management and Environmental Protection, 14(4), 1-8. 